\title{
MINAT NASABAH MENGGUNAKAN MOBILE BANKING DENGAN MENGGUNAKAN KERANGKA TECHNOLOGY ACCEPTANCE MODEL (TAM) (Studi Kasus PT Bank Syariah Mandiri Cabang Yogyakarta)
}

\author{
Imam Sugih Rahayu \\ Prodi Perbankan Syariah STIA Alma Ata Yogyakarta \\ Email: israhayu@bsm.co.id
}

\begin{abstract}
Abstrak
Mobile Banking adalah salah satu pelayanan jasa bank yang memungkinkan nasabah untuk memperoleh informasi, melalui jaringan internet. Penerimaan dan manfaatkan yang dirasakan nasabah secara langsung dinilai berdasarkan persepsi penggunaan melalui kerangka TAM. Oleh karena itu tujuan dari penelitian ini adalah untuk mengetahui Faktor-Faktor Yang Mempengaruhi Minat Nasabah Menggunakan Mobile Bangking Dengan Kerangka Technology Acceptance Model (TAM). Penelitian ini merupakan penelitian survey dengan jenis penelitian kausalitas. Populasi dan sampel dalam penelitian ini nasabah BSM Cabang Yogyakarta yang menggunakan Mobile Banking yang berjumlah 376. Metode pengumpulan menggunakan koesioner yang telah diuji sebelumnya ke 30 responden dan dilakukan uji validitas dan reliabilitas yang menghasilkan $100 \%$ pertanyaan dikatakan valid dan layak untuk digunakan. Metode penelitian menggunakan uji analisis regresi berganda dengan bantuan software SPSS versi 17. Hasil yang diperoeh dari penelitian ini adalah Presepsi manfaat (perceived usefulness) berpengaruh positif terhadap minat perilaku menggunakan Mobile Banking. Dimana tingginya atau meningkatnya Presepsi manfaat (perceived usefulness) maka akan meningkatkan minat perilaku menggunakan Mobile Banking. Persepsi kemudahan penggunaan (perceived ease of use) berpengaruh negatif terhadap minat perilaku menggunakan Mobile Banking. Tingginya Persepsi kemudahan penggunaan (perceived ease of use) akan menurunkan minat perilaku menggunakan Mobile Banking. Presepsi kredibilitas (perceived credibility) berpengaruh positif terhadap minat perilaku menggunakan Mobile Banking. Tingginya Presepsi kredibilitas (perceived credibility) akan meningkatkan minat perilaku menggunakan Mobile Banking. Informasi tentang Mobile Banking berpengaruh positif terhadap perilaku menggunakan Mobile Banking. Tingginya Informasi tentang Mobile Banking akan meningkatkan minat perilaku menggunakan Mobile Banking.
\end{abstract}

JESI

JURNAL EKONOMI

SYARIAH

INDONESIA
Keywords: Mobile Banking, perceived usefulness, perceived ease of use, perceived credibility, information of mobile bangking, behavioral intention. 


\section{PENDAHULUAN}

Banyaknya pengguna internet di Indonesia tentu tidak dapat dipungkiri juga mendorong dunia bisnis untuk lebih maju dan berkembang. Internet menjadimedia dalam melakukan transaksi penjualan dan pembelian. Selain itu internetmenjadi media untuk mencari informasi dan bertukar informasi. Teknologi informasi juga mendorong dunia perbankan untuk ikut andil dalam memanfaatkan internet. Ini merupakan kesempatan bagi dunia perbankan untuk melangkah majudengan memberikan pelayanan yang lebih baik kepada para nasabahnya yaitutidak hanya menawarkan kecepatan dalam melakukan transaksi tetapi jugakemudahan serta kenyamanan bagi nasabah untuk melakukan transaksi keuangan maupun non keuangan secara online tanpa mengharuskan nasabahnya untukdatang dan mengantri di bank atau ATM (Widyarini, 2005). Kemudahan serta kenyamanan ini ditawarkan oleh perbankan melalui layanan Mobile Banking.

Fasilitas Mobile Banking dapat menjawab tuntutan nasabah yang menginginkan layanan cepat, aman, nyaman, murah, dan tersedia setiap saat (24 jam non-stop), serta dapat diakses dari mana saja, cukup melalui telepon seluler. Fasilitas yang ditawarkan Mobile Banking antara lain cek saldo, mutasi 10 transaksi terakhir, transfer (sesama Bank Syariah Mandiri/ BSM atau bank lain), pembayaran tagihan, menu favorit dan lain-lain. Hasil Survei Nielsen menunjukkan bahwa penggunaan Mobile Banking meningkat tiga poin persentase dari 2010, yakni mencapai 37\% pada 2011. Pertumbuhan pengguna online banking di Indonesia juga tercatat sebagai yang tercepat di Asia Tenggara.

Meskipun banyak keuntungan yang didapat oleh nasabah, namun pada kenyataannya layanan ini sangat jarang digunakan oleh nasabah dan cenderung tidak diminati. Nasabah lebih senang melakukan transaksi via ATM atau dengan antri di bank. Pada kenyataannya jumlah pengguna Mobile Banking di Indonesia lebih sedikit dibanding dengan pengguna internet. Pengguna internet di Indonesia mencapai 25 juta dengan populasi 237.512.355 jiwa, sedang pengguna Mobile Banking hanya sebanyak $424.063 \mathrm{di}$ tahun 2004 (Kompas, 2012). Kenyataannya banyak nasabah yang mempunyai fasilitas Mobile Banking namun tidak pernah memanfaatkannya, dikarenakan pengoperasian sistem yang kadang terkesan rumit dan tidak semua orang paham cara menggunakannya. Faktor lain adalah tingkat kemampuan nasabah dalam menggunakan mobile phone, faktor ini juga mempengaruhi minat nasabah dalam menggunakan layanan Mobile Banking. Nasabah yang tidak mampu menggunakan mobile phone, akan mengalami kesulitan dalam mengoperasikan layanan Mobile Banking.

Permasalahan tentang bagaimana nasabah dapat menerima dan memanfaatkan layanan Mobile Banking ini secara maksimal dapat dijelaskan dengan menggunakan kerangka TAM (Theory Acceptance Model). Teori ini menawarkan suatu penjelasan yang kuat dan sederhana untuk penerimaan teknologi dan perilaku para penggunanya (Davis, 1989). Kerangka TAM merupakan model yang dirancang untuk memprediksi penerimaan aplikasi komputer dan faktor-faktor yang berhubungan dengannya (Widyarini, 2005).

Berdasarkan uraian permasalahan mengenai Mobile Banking penulis tertarik untuk melakukan penelitian lebih jauh tentang hal-hal yang mempengaruhi terhadap minat nasabah dalam menggunakan Mobile Banking, maka oleh karena itu untuk melakukan penelitian penulis mengambil judul: "Minat Nasabah Menggunakan Mobile Bangking Dengan Menggunakan

Imam

Sugih

JURNAL EKONOMI SYARIAH INDONESIA, Volume V, No.2 Desember 2015 
Kerangka Technology Acceptance Model (TAM) (Studi Kasus PT Bank Syariah Mandiri)".

Adapun permasalahan secara umum dalam penelitian ini adalah sebagai berikut: Pertama, apakah persepsi manfaat (perceived usefulness) berpengaruh positif terhadap minat perilaku menggunakan Mobile Banking? Kedua, apakah persepsi kemudahan penggunaan (perceived ease of use) berpengaruh positif terhadap minat perilaku untuk menggunakan mobile bangking? Ketiga, apakah persepsi kredibilitas (perceived credibility) berpengaruh positif terhadap minat perilaku menggunakan Mobile Banking? Keempat, apakah informasi tentang Mobile Banking berpengaruh positif terhadap minat perilaku menggunakan Mobile Banking?

Tujuan yang akan dicapai dalam melakukan penelitian ini adalah sebagai berikut: Pertama, untuk mengetahui dan menjelaskan pengaruh persepsi manfaat (perceived usefulness) terhadap minat perilaku menggunakan Mobile Banking. Kedua, untuk mengetahui dan menjelaskan pengaruh persepsi kemudahan penggunaan (perceived ease of use) terhadap minat perilaku untuk menggunakan Mobile Banking. Ketiga, untuk mengetahui dan menjelaskan pengaruh persepsi kredibilitas (perceived credibility) terhadap minat perilaku menggunakan Mobile Banking. Keempat untuk mengetahui dan menjelaskan pengaruh informasi tentang Mobile Banking terhadap minat perilaku menggunakan Mobile Banking.

\section{KAJIAN TEORI DAN HIPOTESIS}

\section{Minat untuk Tetap Menggunakan (Behavioral Intention to Use)}

Perilaku (behaviour) adalah tindakan-tindakan (action) dan reaksi-reaksi (reaction) (Jogiyanto, 2007). Perilaku dapat diartikan sebagai tindakan atau kegiatan nyata yang dilakukan. Perilaku dapat berupa sadar (conscious) atau tidak sadar (unconscious), terus terang (overt) atau diam-diam (covert), sukarela (voluntary) atau tidak sukarela (involuntary). Di samping itu, perilaku manusia dapat berupa perilaku umum (common behavior), tidak umum (uncommon behavior), dapat diterima (acceptable) atau tidak diterima (unacceptable).

Pandangan menurut Arief Hermawan (2008) dalam Suseno (2009) mendefinisikan minat perilaku menggunakan teknologi (behavioral intention to use) sebagai minat (keinginan) seseorang untuk melakukan perilaku tertentu. Menurut Taylor dan Baker (1994) behaviour intention to use diartikan sebagai keinginan individu untuk menggunakan kembali sesuatu yang sama apabila suatu waktu memerlukan kembali.

\section{Teori Technology Acceptance Model (TAM)}

Beberapa model yang dibangun untuk menganalisis dan memahami faktor-faktor yang mempengaruhi diterimanya penggunaan teknologi komputer, diantaranya yang tercatat dalam berbagai literatur dan referensi hasil riset dibidang teknologi informasi contohnya adalah Theory of Reasoned Action (TRA), Theory of Planned Behaviour (TPB), dan Technology Acceptance Model (TAM). Model TAM sebenarnya diadopsi dari model TRA yang

Minat Nasabah diperkenalkan oleh Ajzen dan Fishbein (1980) dan diusulkan oleh Davis (1989), yaitu teori tindakan yang beralasan dengan satu premis bahwa reaksi dan persepsi seseorang terhadap sesuatu hal, akan menentukan sikap dan perilaku orang tersebut. Davis pada tahun 1986 dengan disertasinya yang berjudul " $A$ Technolog Acceptance Model for Empirically Testing New End-User Information 
System: Theory and Results" di Sloan School of Management, Massachusetts Institute of Technology. Disertasi ini selanjutnya dipublikasikan dalam karya ilmiah yang berjudul "Perceived Usefulness, Perceived Ease of Use, and User Acceptance of Information Technology".

Sesuai dengan TAM, penggunaan sistem (actual system usage) paling dipengaruhi oleh minat untuk menggunakan (behavioral intentions toward usage). Behavioral intentions toward usage dipengaruhi oleh dua kepercayaan, yaitu persepsi pengguna terhadap manfaat (perceived usefulness) dan persepsi pengguna terhadap kemudahan (perceived ease of use). Perceived usefulness diartikan sebagai tingkat dimana seseorang percaya bahwa menggunakan sistem tertentu dapat meningkatkan kinerjanya, dan perceive ease of use diartikan sebagai tingkat dimana seseorang percaya bahwa menggunakan sistem tidak diperlukan usaha apapun (free of effort). Perceive ease of use juga berpengaruh pada perceived usefulness yang dapat diartikan bahwa jika seseorang merasa sistem tersebut mudah digunakan maka sistem tersebut berguna bagi mereka. Penelitian ini mengacu pada penelitian terdahulu yang dilakukan oleh Wang et al. (2003) yang ada pada gambar 1. Penelitian tersebut mengambil sampel orang dewasa di Taiwan yang sebelumnya pernah melakukan transaksi menggunakan Mobile Banking.

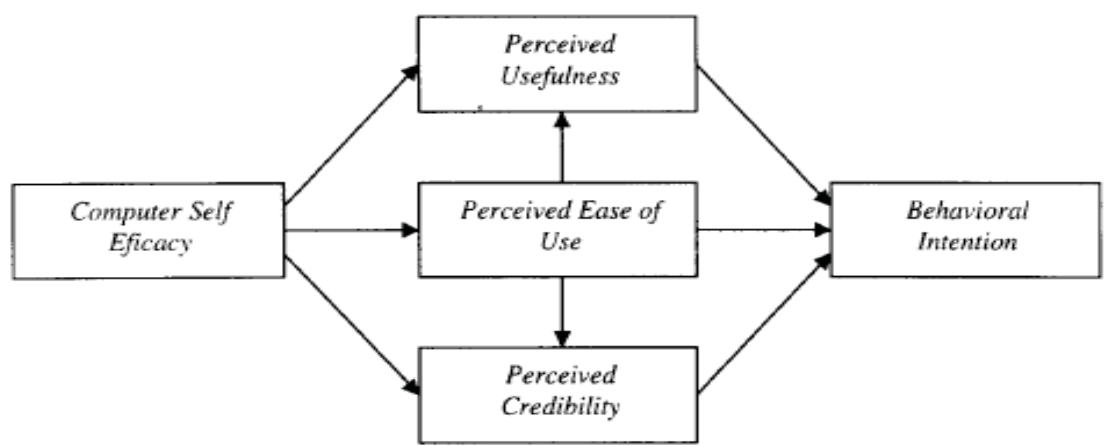

Gambar 1. Pengembangan Technology Acceptance Model (TAM) (Wang et al. (2003))

Beberapa kelebihan TAM sebagai berikut: TAM merupakan model perilaku yang bermanfaat untuk menjawab kegagalan penerapan sistem TI karena tidak adanya minat para pengguna untuk menggunakannya; TAM dibangun dengan dasar teori yang kuat; TAM telah diuji dengan banyak penelitian dan sebagian besar hasilnya mendukung bahwa TAM merupakan model yang baik; dan TAM merupakan model parsimoni yaitu model sederhana dan valid.

Meskipun demikian, model TAM juga memiliki beberapa kelemahan, diantaranya adalah sebagai berikut: TAM hanya memberikan informasi atau hasil yang sangat umum tentang minat dan perilaku pengguna dalam menerima TI; TAM tidak memiliki kontrol perilaku; Penelitian TAM umumnya hanya menggunakan sebuah sistem TI; TAM kurang dapat menjelaskan sepenuhnya hubungan antar variabel di dalam model; dan TAM tidak mempertimbangkan perbedaan kultur. 


\section{Pengaruh Antar Variabel}

Pengaruh persepsi manfaat (perceived usefulness) terhadap minat perilaku menggunakan Mobile Banking

Davis $(1986,1989)$ dan Adam et.al., (1992) mendefinisikan kemanfaatan (usefulness) sebagai suatu tingkatan seseorang percaya bahwa penggunaan suatu teknologi tertentu akan meningkatkan prestasi kerja orang tersebut. Menurut Davis (1989); Mathieson (1991); serta Venkatesh dan Davis (2000) manfaat (perceived of usefulness) merupakan penentu yang kuat terhadap penerimaan penggunaan suatu sistem informasi, adopsi, dan perilaku para pengguna. Berdasarkan uraian di atas, maka diajukan hipotesis penelitian sebagai berikut:

H1: Presepsi manfaat (perceived usefulness) berpengaruh positif minat perilaku menggunakan Mobile Banking.

Pengaruh persepsi kemudahan penggunaan (perceived ease of use) terhadap minat perilaku menggunakan Mobile Banking

Persepsi kemudahan penggunaan (Perceived ease of use) didefinisikan sebagai suatu tingkat kepercayaan individu bahwa dengan menggunakan teknologi akan membawa mereka terbebas dari usaha secara fisik dan mental (Gardner dan Amoroso, 2004). Persepsi tentang kemudahan penggunaan sebuah teknologi didefinisikan sebagai suatu ukuran dimana seseorang percaya bahwa, komputer dapat dengan mudah dipahami dan digunakan

Hasil penelitian dari Chau dan Lai (2003) menunjukkan bahwa kemudahan dalam penggunaan sistem memiliki pengaruh positif signifikan pada minat penggunaan Internet Banking. Berdasarkan uraian di atas, maka diajukan hipotesis penelitian sebagai berikut:

H2: Persepsi kemudahan penggunaan (perceived ease of use) berpengaruh positif pada minat perilaku untuk menggunakan Mobile Banking.

\section{Pengaruh persepsi kredibilitas (perceived credibility) terhadap minat perilaku menggunakan Mobile Banking}

Perceived credibility atau sering disebut sebagai persepsi pengguna terhadap kredibilitas didefinisikan sebagai tingkat dimana kepercayaan seseorang terhadap bahwa sistem yang digunakan tetap menjamin keamanan dan privasinya (Wang et. Al. 2003). Hal ini berkaitan dengan bagaimana nasabah merasa nyaman dan aman dalam menggunakan Mobile Banking, jika nasabah merasa hal tersebut dapat terpenuhi maka tentunya rasa puas akan muncul seiring dengan penggunaannya.

Berdasarkan uraian di atas, maka diajukan hipotesis penelitian sebagai berikut:

H3: Presepsi kredibilitas (perceived credibility) berpengaruh positif minat perilaku menggunakan Mobile Banking.

\section{Minat}

Nasabah

141

\section{Hubungan informasi tentang Mobile Banking terhadap minat perilaku menggunakan Mobile Banking}

Dukungan empiris tentang hubungan sebab akibat antara pengetahuan baru tentang teknologi dan minat penggunaan (Polatoglu dan Ekin, 2001; Sathye, 1999; dan Howard dan Moore, 1982). Studi mengkonfirmasi informasi penting tentang teknologi yang baru muncul. Penelitian Polatoglu dan Ekin 
(2001) menemukan terdapat pengaruh yang signifikan antara pengetahuan yang dimiliki oleh konsumen dan Mobile Banking.

Berdasarkan uraian di atas, maka diajukan hipotesis penelitian sebagai berikut:

H4: Informasi tentang Mobile Banking berpengaruh positif minat perilaku menggunakan Mobile Banking.

\section{Kerangka Pemikiran}

Dari hasil diskusi seperti diatas dapat disimpulkan bawa dari uraian tersebut diatas maka dikembangkan kerangka pemikiran teoritis sebagaimana terlihat dalam gambar Gambar 2 sebagai berikut ini:

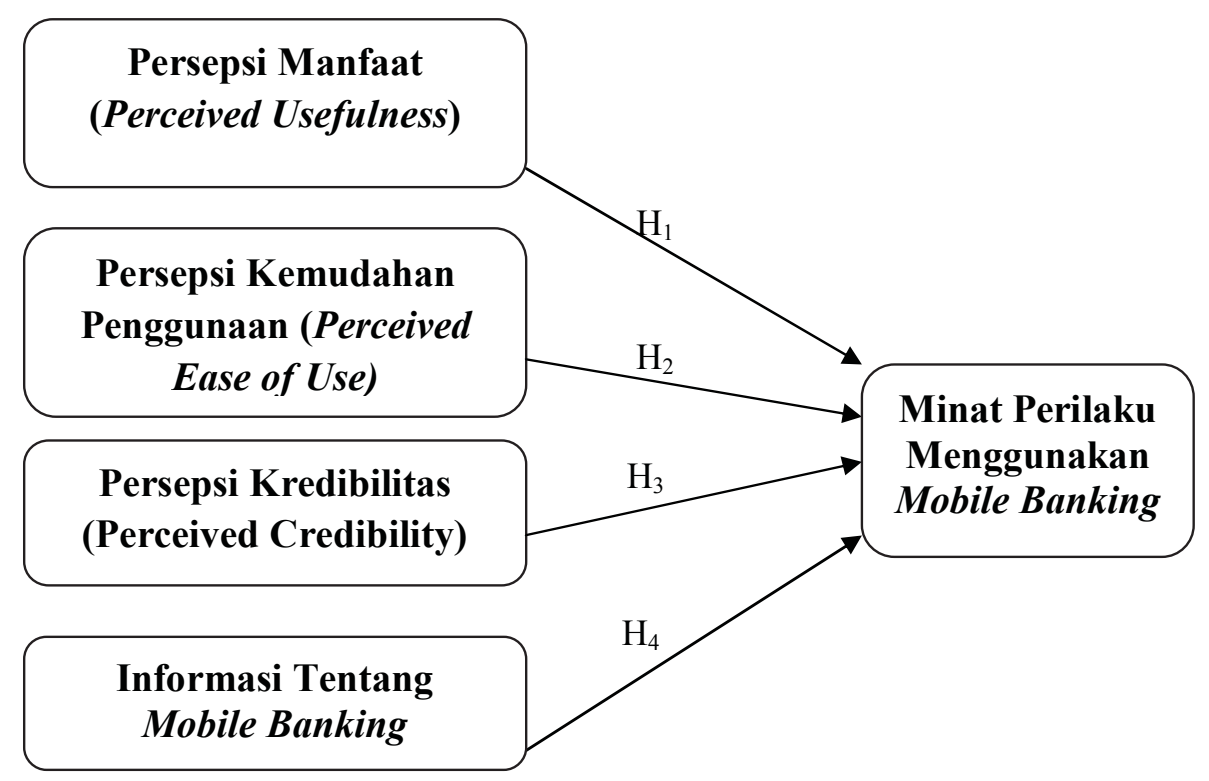

Gambar 1. Kerangka Pemikiran Pengembangan

Pengembangan Wang et al. (2003) dan Hanudin, Rizal, Suddin Zuraidah (2008)

Konsep pemikiran dalam penelitian ini mengembangkan dan mengadopsi dari penelitian sebelumnya yaitu Wang et al. (2003) dan Hanudin et al. (2008). Adapun perbedaan dalam penelitian ini adalah pada kerangka konsep dimana pada penelitian Wang et al dimana perceived ease of use berpengaruh positif terhadap perceived usefulness dan perceived credibility. Begitu juga dengan penelitian yang telah dilakukan oleh Hanudin, Rizal, Suddin Zuraidah.

\section{METODE PENELITIAN}

\section{Jenis pendekatan dan penelitian}

Penelitian ini merupakan jenis penelitian survey, yaitu penelitian yang dilakukan dengan mengambil sampel secara langsung yang mengambil data dari para nasabah (populasi), sehingga ditemukan hubungan-hubungan antar variabel (Sugiyono, 2008). Sedangkan dilihat dari cakupan jenis eksplanasi ilmunya, penelitian ini merupakan penelitian kausalitas, yang bertujuan untuk mencari penjelasan dalam bentuk hubungan sebab akibat antara beberapa variabel yang dikembangkan dalam penelitian melalui pengujian hipotesis. Sementara itu, pendekatan penelitian ini adalah pendekatan kuantitatif dengan desain paradigma positivistik (Ferdinand, 2006) 


\section{Populasi dan Sampel}

Dalam penelitian ini populasi sasaran yang dimaksud adalah nasabah BSM Cabang Yogyakarta baik yang sudah maupun yang belum memiliki fasilitas Mobile Banking. Jumlah populasi nasabah yang menggunakan Mobile Banking sebanyak 6.320 nasabah.

Adapun teknik sampel yang dugunakan adalah Convenience Sampling atau Accidental Sampling, mengambil responden sebagai sampel berdasarkan kebetulan yaitu siapa saja yang secara kebetulan ditemui cocok sebagai sumber data dengan kriteria utamanya adalah orang yang merupakan konsumen atau user. Rumus yang digunakan untuk menentukan sampel yaitu menggunakan rumus Slovin dalam Husein Umar (2007), yaitu sebagai berikut :

$$
n=\frac{N}{1+N e^{2}}
$$

Keterangan:

$\mathrm{n}$ : Ukuran sampel

$\mathrm{N}$ : Ukuran Populasi

$e \quad$ : Persentasi ketidaktelitian karena kesalahan dalam pengambilan sampel dalam penelitian diambil 5\%.

$$
n=\frac{6320}{1+6320(0,05)^{2}}=376
$$

Berdasakan perhitungan rumus di atas dapat dilihat dengan jumlah populasi 6320 dengan tingkat kesalahan (taraf signifikansi) sebesar 5\% di peroleh jumlah sampel sebesar 376 . Oleh karena itu dapat dipastikan bahwa jumlah sampel yang digunakan dalam penelitian ini adalah 376 nasabah.

\section{HASIL ANALISIS DAN PEMBAHASAN}

\section{Pengolahan Data}

\section{Analisis Regresi Linier Berganda}

Hasil penghitungan untuk analisis regresi linier berganda dalam penelitian ini pada Tabel 1.

Tabel 1. Analisis Regresi Linier Berganda

\begin{tabular}{lcc}
\hline & \multicolumn{2}{c}{ Unstandardized Coefficients } \\
& B & Std. Error \\
\hline (Constant) & 7,653 & 0,855 \\
PU & 0,106 & 0,043 \\
PEU & $-0,117$ & 0,047 \\
PC & 0,324 & 0,054 \\
IMB & 0,084 & 0,038 \\
\hline \multicolumn{2}{c}{ Sumber: Olah Data SPSS }
\end{tabular}

Minat

Nasabah

Berdasarkan tabel 4.10 di atas diperoleh bentuk model persamaan regresi sebagai berikut:

$$
\mathrm{Y}=7,653+0,106 \mathrm{X}_{1}-0,117 \mathrm{X}_{2}+0,324 \mathrm{X}_{3}+0,084 \mathrm{X}_{4}+\mathrm{e}
$$


Pengujian hipotesis ditunjukan untuk menguji ada tidaknya pengaruh dari variabel independent secara keseluruhan terhadap variabel dependent. Pengujian hipotesis menggunakan uji statistik yaitu uji F secara bersamaan, uji secara t secara parsial dan koefisien determinasi $\left(\mathrm{R}^{2}\right)$. Berikut hasil pengujian hipotesis adalah:

\section{Uji t (Secara Parsial)}

Uji t pada dasarnya menunjukan pengaruh variabel independent secara parsial dalam menerangkan variansi variabel dependent. Dalam penelitian ini untuk melihat pengaruh persepsi manfaat (perceived usefulness), persepsi kemudahan penggunaan (perceived ease of use), persepsi kredibilitas (perceived credibility), informasi tentang Mobile Banking secara parsial terhadap minat perilaku menggunakan Mobile Banking. Adapun hasil uji t sebagai berikut:

Tabel 2. Uji t

\begin{tabular}{lcccc}
\hline \multicolumn{1}{c}{ Variabel } & $\mathrm{T}_{\text {hitung }}$ & $\mathrm{t}_{\text {tahel }}$ & Sig & Keterangan \\
\hline $\begin{array}{l}\text { persepsi manfaat (perceived } \\
\begin{array}{l}\text { usefulness) } \\
\text { persepsi kemudahan }\end{array}\end{array}$ & 2,491 & 1,649 & 0,013 & Signifikan \\
$\begin{array}{l}\text { penggunaan (perceived ease of } \\
\text { use) } \\
\text { persepsi kredibilitas (perceived } \\
\text { credibility) }\end{array}$ & $(-) 2,499$ & 1,649 & 0,013 & Signifikan \\
$\begin{array}{l}\text { informasi tentang Mobile } \\
\text { Banking }\end{array}$ & 2,1974 & 1,649 & 0,000 & Signifikan \\
\hline
\end{tabular}

Sumber: Data Diolah SPSS

Pada tabel 2 diperoleh nilai $\mathrm{t}$ dapat dicari dengan level of significance (a) $=0,05$ dan derajat tabel kebebasan (degree of freedom $=\mathrm{df}$ ) $=\mathrm{n}-\mathrm{k}-1$, maka besarnya nilai t-tabel dapat ditentukan sebagai berikut: $\mathrm{t}$-tabel adalah a ; $\mathrm{n}-\mathrm{k}$ $=0,05 ;(376-3)=1,649$. Adapun cara pengujian uji t untuk masing-masing variabel adalah sebagai berikut:

Hipotesis 1 menunjukan terdapat pengaruh positif dan signifikan Presepsi manfaat (perceived usefulness) terhadap minat perilaku menggunakan Mobile Banking. Pembuktian untuk hipotesis tersebut digunakan perbandingan thitung dengan $t$ tabel, dimana diperoleh nilai thitung lebih besar dari pada $t$ tabel $(2,491>1,649)$ dan nilai signifikansi lebih kecil dari pada alpha $(0,013<$ $0,05)$. Maka dapat disimpulkan bahwa hipotesis 1 terbukti diterima. Signifikan menjelaskan bahwa presepsi manfaat (perceived usefulness) berpengaruh minat perilaku menggunakan Mobile Banking, sedangkan pengaruh positif dengan kata lain tingginya persepsi manfaat (perceived usefulness) akan meningkatkan minat perilaku menggunakan Mobile Banking.

Hipotesis 2 menunjukan terdapat pengaruh negatif dan signifikan Persepsi kemudahan penggunaan (perceived ease of use) terhadap minat perilaku menggunakan Mobile Banking. Pembuktian untuk hipotesis tersebut digunakan perbandingan $\mathrm{t}$ hitung dengan $\mathrm{t}$ tabel, dimana diperoleh nilai $\mathrm{t}$ hitung lebih besar dari pada $t$ tabel $(2,499<1,649)$ dan nilai signifikansi lebih kecil dari pada alpha $(0,013<0,05)$. Maka dapat disimpulkan bahwa hipotesis 2 terbukti diterima dengan pengaruh negatif. Signifikan menjelaskan bahwa persepsi kemudahan penggunaan (perceived ease of use) berpengaruh terhadap minat perilaku menggunakan Mobile Banking, sedangkan pengaruh negatif

Imam Sugih

JURNAL EKONOMI SYARIAH INDONESIA, Volume V, No.2 Desember 2015 
dengan kata lain tingginya persepsi kemudahan penggunaan (perceived ease of use) akan menurunkan minat perilaku menggunakan Mobile Banking.

Hipotesis 3 menunjukan terdapat pengaruh positif dan signifikan persepsi kredibilitas (perceived credibility) terhadap minat perilaku menggunakan Mobile Banking. Pembuktian untuk hipotesis tersebut digunakan perbandingan $t$ hitung dengan $t$ tabel, dimana diperoleh nilai t hitung lebih besar dari pada $t$ tabel $(5,974>1,649)$ dan nilai signifikansi lebih kecil dari pada alpha $(0,000<$ 0,05). Maka dapat disimpulkan bahwa hipotesis 3 terbukti diterima. Signifikan menjelaskan bahwa persepsi kredibilitas (perceived credibility) berpengaruh minat perilaku menggunakan Mobile Banking, sedangkan pengaruh positif dengan kata lain tingginya persepsi kredibilitas (perceived credibility) akan meningkatkan minat perilaku menggunakan Mobile Banking.

Hipotesis 4 menunjukan terdapat pengaruh positif dan signifikan Informasi tentang Mobile Banking berpengaruh positif terhadap minat perilaku menggunakan Mobile Banking. Pembuktian untuk hipotesis tersebut digunakan perbandingan $\mathrm{t}$ hitung dengan $\mathrm{t}$ tabel, dimana diperoleh nilai $\mathrm{t}$ hitung lebih besar dari pada $t$ tabel $(2,198>1,649)$ dan nilai signifikansi lebih kecil dari pada alpha $(0,029<0,05)$. Maka dapat disimpulkan bahwa hipotesis 4 terbukti diterima. Signifikan menjelaskan bahwa informasi tentang Mobile Banking berpengaruh minat perilaku menggunakan Mobile Banking, sedangkan pengaruh positif dengan kata lain tingginya informasi tentang Mobile Banking akan meningkatkan minat perilaku menggunakan Mobile Banking.

\section{Uji F (Secara Bersamaan)}

Uji F digunakan untuk melihat atau menunjukan pengaruh variabel independent secara bersamaan terhadap variabel dependent. Dalam penelitian untuk melihat ada tidaknya pengaruh persepsi manfaat (perceived usefulness), persepsi kemudahan penggunaan (perceived ease of use), persepsi kredibilitas (perceived credibility), informasi tentang Mobile Banking secara bersamaan terhadap minat perilaku menggunakan Mobile Banking. Berikut hasil analisis uji F sebagai berikut:

Tabel 3. Uji F

\begin{tabular}{lcccc}
\hline \multicolumn{1}{c}{ Model } & F & Ftabel & Sig. & Keterangan \\
\hline $\begin{array}{l}\text { persepsi manfaat (perceived } \\
\text { usefulness), persepsi kemudahan } \\
\text { penggunaan (perceived ease of use), }\end{array}$ & 15,296 & 2,41 & $0,000^{\mathrm{a}}$ & Signifikan \\
persepsi kredibilitas (perceived & & & & \\
credibility), informasi tentang & & & & \\
Mobile Banking & & & & \\
\hline
\end{tabular}

Sumber: Data Diolah SPSS

Pada Tabel 3 diperoleh nilai $\mathrm{F}_{\text {tabel }}$ dapat dicari dengan melihat pada tabel $\mathrm{F}$, dimana level of significance $(\mathrm{a})=0,05$ dan degree of freedom $(\mathrm{dfl})=\mathrm{k}+1=4+1=5$ dan df2 $=\mathrm{n}-\mathrm{df} 1=376-5=371$, maka diperoleh nilai $\mathrm{F}_{\text {tabel }} 2$,41. Berdasarkan tabel di atas diperoleh nilai $\mathrm{F}$ hitung sebesar 15,296, perbandingan dengan $\mathrm{F}$ tabel diperoleh bahwa nilai $\mathrm{F}$ hitung lebih besar dari pada $\mathrm{F}$ tabel $(15,296$ Minat $>2,41)$ dan nilai signifikansi lebih kecil dari pada alpha $(0,000<0,05)$. Maka Nasabah dapat disimpulkan bahwa hipotesis kedua terbukti diterima. Artinya terdapat pengaruh positif dan signifikan persepsi manfaat (perceived usefulness), persepsi 
credibility), informasi tentang Mobile Banking secara bersamaan terhadap minat perilaku menggunakan Mobile Banking.

\section{Koefisien Determinasi}

Koefisien determinasi berfungsi untuk melihat kemampuan variabel independent menerangkan variabel dependent dapat diketahui dari besarnya koefisien determinasi $\left(R^{2}\right)$. Penilaian koefisien determinasi secara bersamaan dalam model SPSS dilihat dari nilai adjusted $R$ square, pada tabel sebagai berikut:

Tabel 4. Koefisien Determinasi

\begin{tabular}{ccc}
\hline $\mathrm{R}$ & $\mathrm{R}$ Square & Adjusted R Square \\
\hline 0,376 & 0,142 & 0,132 \\
\hline
\end{tabular}

Sumber: Data Diolah SPSS

Berdasarkan Tabel 4. diperoleh nilai koefisien determinasi sebesar 0,132, maka dapat diartikan bahwa kontribusi yang diberikan persepsi manfaat (perceived usefulness), persepsi kemudahan penggunaan (perceived ease of use), persepsi kredibilitas (perceived credibility), informasi tentang Mobile Banking terhadap minat perilaku menggunakan Mobile Banking sebesar 13,2\%, sedangkan sisanya sebesar $86,8 \%$ dipengaruhi oleh faktor lain.

\section{PEMBAHASAN}

Presepsi manfaat (perceived usefulness) berpengaruh positif pada minat perilaku menggunakan Mobile Banking

Berdasarkan hasil analisis diperoleh nilai thitung lebih besar dari pada $\mathrm{t}$ tabel $(2,499>1,649)$ dan nilai signifikansi lebih kecil dari pada alpha $(0,013$ $<0,05)$. Maka dapat disimpulkan bahwa hipotesis 1 terbukti. Pengaruh positif dengan kata lain tingginya persepsi manfaat (perceived usefulness) akan meningkatkan minat perilaku menggunakan Mobile Banking.

Persepsi kemudahan penggunaan (perceived ease of use) berpengaruh negatif pada minat perilaku untuk menggunakan Mobile Banking

Berdasarkan hasil penelitian diperoleh nilai $t$ hitung lebih besar dari pada $t$ tabel $(2,499>1,649)$ dan nilai signifikansi lebih kecil dari pada alpha $(0,013<0,05)$. Maka dapat disimpulkan bahwa hipotesis 2 terbukti diterima dengan pengaruh negatif. Pengaruh negatif dengan kata lain tingginya persepsi kemudahan penggunaan (perceived ease of use) akan menurunkan minat perilaku menggunakan Mobile Banking.

Presepsi kredibilitas (perceived credibility) berpengaruh positif pada minat perilaku menggunakan Mobile Banking

Berdasarkan hasil penelitian nilai thitung lebih besar dari pada $t$ tabel $(5,974>1,649)$ dan nilai signifikansi lebih kecil dari pada alpha $(0,000<0,05)$. Maka dapat disimpulkan bahwa hipotesis 3 terbukti diterima. Pengaruh positif dengan kata lain tingginya presepsi kredibilitas (perceived credibility) akan meningkatkan minat perilaku menggunakan Mobile Banking. .

Informasi tentang Mobile Banking berpengaruh positif minat perilaku menggunakan Mobile Banking

Berdasarkan hasil penelitian diperoleh nilai t hitung lebih besar dari pada $t$ tabel $(2,198>1,649)$ dan nilai signifikansi lebih kecil dari pada alpha $(0,029<0,05)$. Maka dapat disimpulkan bahwa hipotesis 4 terbukti diterima.

Imam

Sugih

JURNAL EKONOMI SYARIAH INDONESIA, Volume V, No.2 Desember 2015 
Pengaruh positif dengan kata lain tingginya Informasi tentang Mobile Banking akan meningkatkan minat perilaku menggunakan Mobile Banking.

\section{KESIMPULAN}

Berdasarkan analisis dan hasil penelitian, maka penelitian ini menyimpulkan bahwa:

Presepsi manfaat (perceived usefulness) berpengaruh positif terhadap minat perilaku menggunakan Mobile Banking. Dimana tingginya atau meningkatnya Presepsi manfaat (perceived usefulness) maka akan meningkatkan minat perilaku menggunakan Mobile Banking.

Persepsi kemudahan penggunaan (perceived ease of use) berpengaruh negatif terhadap minat perilaku menggunakan Mobile Banking. Tingginya Persepsi kemudahan penggunaan (perceived ease of use) akan menurunkan minat perilaku menggunakan Mobile Banking. Hal ini dikarenakan system perbankan yang digunakan untuk mengakses Mobile Banking sering mengalami offline atau error system, sehingga menimbulkan persepsi kekhawatiran dan kekecewaan dalam penggunaan. Oleh karena itu timbul keraguan nasabah dalam penggunaanya, sehingga semakin tingginya tingkat offline atau error system akan menurunkan minat nasabah.

Presepsi kredibilitas (perceived credibility) berpengaruh positif terhadap minat perilaku menggunakan Mobile Banking. Tingginya Presepsi kredibilitas (perceived credibility) akan meningkatkan minat perilaku menggunakan Mobile Banking.

Informasi tentang Mobile Banking berpengaruh positif terhadap perilaku menggunakan Mobile Banking. Tingginya Informasi tentang Mobile Banking akan meningkatkan minat perilaku menggunakan Mobile Banking.

\section{DAFTAR PUSTAKA}

Adams, D.A., R.R. Nelson \& P. A. Todd. 1992. Perceives Usefulness, Ease of Use, and Usage of Information Technology: A Replication. MIS Quarterly. Vol. 16 No. 2: Hal. 227-247

Alter, S. 2002. Information System: The Foundation of E-business. New Jersey: Prentice Hall.

Arikunto, Suharsimi. 2006. Prosedur Penelitian Suatu Pendekatan Praktik, Ed Revisi VI,. Penerbit PT Rineka Cipta

Ba, S. \& P. A. Pavlou. 2002. Evidence of The Effect of Trust Building Technology in Electronic Markets: Price Premiums and Buyer Behavior. Managing Information System Quaterly, Vol 26, No 3, page 243- 268.

Chau, P.Y.K. and Lai, V.S.K. 2003. “An empirical investigation of the determinants of user acceptance of internet banking". Journal of Organizational Computing \& Electronic Commerce. Vol. 13 No. 2, pp. 123-45

Chan, S.C. and Lu, M., 2004. Understanding internet banking adoption and use behavior: A Hong Kong perspective. Journal of Global Information

Minat

Nasabah Management (online journal from Proquest), Vol. 12, Iss. 3, pg. 21

Cheng TCE, Lam DYC, Yeung ACL. 2006. Adoption of internet banking: an empirical study in Hong Kong. Decis Support Syst., 42(3):1558-72. 
Cheong, J.H., and Park, M.C. 2005. Mobile internet acceptance in Korea. Internet Research, 15, 125-140.

Chiu, Y.B., Lin, C.P., and Tang, L.L. 2005. Gender differs: Assessing a model of online purchase intentions in e-tail service. International Journal of Service Industry Management, 16, 416-435.

Davis, F.D., 1989. Perceived usefulness, perceived ease of use, and user acceptance of information technology. MS Quarterly (online), Vol. 13 Iss. 3, pg. 318.

Davis, F.D., Bagozzi, R.P., and Warshaw, P.R., 1989. User acceptance of computer technology: A comparison of two theoretical models. Management Science (online), Vol. 35 Iss. 8, pg. 982.

Ferdinand, Augusty. 2006. Metode Penelitian Manajemen. Semarang: BP Undip.

Gardner, C. Amoroso. D. 2004. Development Of An Instrument To Measure The Acceptance Of Internet Technology By Consumers," Proceedings of the 37th Hawaii International Conference on System Sciences, USA

Ghozali, Imam. 2009. Aplikasi Analisis Multivariate Dengan Program SPSS, Edisi. Keempat, Penerbit Universitas Diponegoro.

Hanudin A, Mohd Rizal AH, Suddin L, Zuraidah A. 2008. The adoption of mobile banking in Malaysia: the case of Bank Islam Malaysia Berhad (CIMB). Int. J. Bus. Soc., 9(2): $43-53$

Hong, W., Thong, J.Y.L., Wong, W.M., and Tam, K.Y., 2000. Determinants of user acceptance of digital libraries: An empirical examination of individual differences and systems characteristics. Journal of Management Information Systems (online journal from Proquest), Vol. 18, Iss. 3, pg. 97

Howard, J., and Moore, W. (1982). Changes in consumer behavior over the product life cycle. In M. Tushman and

Howcroft, B., Hamilton, R., and Hewer, P. 2002. Consumer attitude and the usage and adoption of home-based banking in the United Kingdom. International Journal of Bank Marketing, 20, 111-121.

Istiarni, Panggih RW. 2014. Analisis Pengaruh Persepsi Manfaat, Kemudahan Penggunaan Dan Kredibilitas Terhadap Minat Penggunaan Berulang Internet Banking Dengan Sikap Penggunaan Sebagai Variabel Intervening. Skripsi. Universitas Diponegoro Semarang

Jogiyanto. 2007. Sistem Informasi Keperilakuan (Edisi Revisi ed.). Yogyakarta: C.V Andi Offset

Lee, M.C. 2008. Factors Influencing the Adoption of Internet Banking: An Integration of TAM and TPB wit Perceived Risk and Perceived Benefit. Journal of Electronic Research and Aplication, No. 51

Liao, Chun-Hsiung, Tsou, Chung-Wang, dan Kao, Yu-Chi. 2007. “Explaining Consumer Acceptance of Online Digital Music". Proceedings of the 13 th Asia Pasific Management Conference, Melbourne, Australia.

Luarn, Pin dan Hsin-Hui Lin. 2005. Toward an Understanding Of The Behavioral Intention to Use Mobile Banking. Elsevier. Journal of Computers in Human Behavior, 21, 873-891

Maharsi, Sri dan Fenny. 2006. "Analisa Faktor-faktor yang Mempengaruhi Kepercayaan dan pengaruh Kepercayaan terhadap Loyalitas Pengguna

JURNAL EKONOMI SYARIAH INDONESIA, Volume V, No.2 Desember 2015 
Internet Banking di Surabaya". Jurnal Akuntansi dan Keuangan, Vol. 8, No. 1, Mei 2006.

Mukherjee, A. dan Nath P. A. 2003. Model of Trust in Online Relationship Banking. International Journal of Banking.

Pikkarainen, T., Pikkarainen, K., Karjaluoto, H., and Pahnila, S. (2004). Consumer acceptance of online banking: An extension of the technology acceptance model. Internet Research, 14, 224-235.

Pavlou, P. A. \& D. Gefen, 2004, Building Effective Online Marketplaces With Institution Based.

Polatoglu, V.N., and Ekin, S. 2001. An empirical investigation of the Turkish consumers' acceptance of Internet banking services. International Journal of Bank Marketing, 19, 156-165.

Rahadi, Dedi R. 2007. Peranan Teknologi Informasi Dalam Peningkatan Pelayanan Di SektoR Publik. Seminar Nasional Teknologi, Yogyakarta.

Riyadh, A. N., M. S. Akter \& N. Islam. 2009. The Adoption of E-Banking in Developing Countries: A Theoritical Model for SMEs. International Review of Business Research Papers, Vol 5, No 6, page 212-230.

Schiffman, Leon G and Kanuk, Leslie Lazar. 1994. Consumer Behavior. New Jersey: Prentice Hall, 1994.

Sugiyono. 2008. Metode Penelitian Bisnis. Bandung: CV Alfabeta

Sugiyono. 2013. Metode Pendekatan Penelitian (Kuantitatif, Kualitatif dan RED). Bandung: CV Alfabeta

Sun, Heshan dan Zhang, Pin. 2006 "Causal Relationship Between Perceived Enjoyment and Perceived Ease of Use: An Alternative Approach". Journal of the Association for Information Systems, Vol. 7, No.9.

Taylor A, Steven and Baker. (1994). "An Assesment of the Relationship betweenService Quality and Customer Satisfaction in the Information of Customers Purchase Intentions", Journal of retailing, Vol.70. No.2 p.163178, NewYork University.

Tampubolon, Manahan P. 2004. Perilaku Keorganisasian (Organization Behavior). Cetakan Pertama, Ghalia Indonesia, Jakarta

Umar, Husein. 2007. Metode Penelitian Untuk Skripsi Dan Tesis Bisnis,. Jakarta: PT. Raja Grafindo Persada

Venkatesh, V., and Morris, M.G. (2000). Why don't men ever stop to ask for directions: Gender, social influence and their role in technology acceptance and usage behavior. MIS Quarterly, 24, 115-139.

W.L. Moore (Eds.), Readings in the management of innovation, Pitman, 128.

Wang, Y.S., 2002. The adoption of electronic tax filing systems: An empirical study. Government Information Quarterly (online), Vol. 20, pg. 333.

Wang, Y.S., Wang, Y.M., Lin, H.H., and Tang, T.I., 2003. Determinants of user acceptance of internet banking: An empirical study. International Journal

Minat

Nasabah of Service Industry Management (online journal from Proquest), Vol.14, Iss.5, pg. 501. 
Wibowo, Arief. 2006. Kajian tentang Perilaku Pengguna Sistem Informasi dengan Pendekatan Technology Acceptance Model (TAM), Universitas Budi Luhur, Jakarta

Widjajanto, Nugroho. 2001. Sistem Informasi Akuntansi. Jakarta: Erlangga

Widyarini, A Lydia. 2005. Analisis Niat Perilaku Menggunakan Internet Banking di Kalangan Pengguna Internet di Surabaya". Surabaya: Jurnal Widya Manajemen \& Akuntansi. 